\title{
Measuring the Physico-Chemical Impact of Wastewater from the Open Sewer in an Industrial Area: Case of the Kossodo Industrial Area in the City of Ouagadougou in Burkina Faso
}

\author{
Bernard Gouba ${ }^{1}$, Madjoyogo Hervé Sirima ${ }^{2,3}$ \& Betaboale Naon ${ }^{4}$ \\ ${ }^{1}$ Civil Engineering Department, Distant Production House University, Kigali, Rwanda \\ ${ }^{2}$ Mechanization Department, Research Institute in Applied and Technological Sciences - National Center for \\ Scientific and Technological Research, Ouagadougou, Burkina Faso \\ ${ }^{3}$ Center for Applied Research in Industrial Systems Engineering, Ouagadougou, Burkina Faso \\ ${ }^{4}$ Study and Research Group in Mechanics, Energetics and Industrial Technics, University Institute of Technology, \\ Nazi Boni University, Bobo - Dioulasso, Burkina Faso \\ Correspondence: Bernard Gouba, Civil Engineering Department, Distant Production House University, Kigali, \\ Rwanda. E-mail: adarasango@yahoo.fr; madjoyogo2@yahoo.fr; betaboale@yahoo.fr
}

Received: March 13, 2021

doi:10.5539/ep.v10n1p46
Accepted: March 27, 2021

Online Published: March 28, 2021

URL: https://doi.org/10.5539/ep.v10n1p46

\begin{abstract}
Wastewater from industrial units in the Kossodo district in the city of Ouagadougou has a physicochemical impact on the environment and the population. For several years the Kossodo area was famous for the effects of wastewater from industrial units on the environment (a foul odor). We took samples from various points of the open canals in order to determine the physico-chemical parameters of this wastewater. This choice was guided by a concern to measure the physico-chemical impact of wastewater from the open sewer in the industrial zone of Kossodo in the city of Ouagadougou on the one hand and to show the danger represented by this wastewater from industrial units on the environment and public health on the other hand.

The objective also guided the choice of the parameters retained for the measurement of the physicochemical impact of the industrial units wastewater of the open sewer of Kossodo zone in the city of Ouagadougou: MES, DCO, $\mathrm{BOD}_{5}, \mathrm{pH}$, Potassium, Sodium.
\end{abstract}

The results show that the wastewater from the open sewers of the industrial units of Kossodo in the city of Ouagadougou, has a high physicochemical parameter content than the authorized discharge standard.

Keywords: measurement, physico-chemical impact, wastewater, open sewer

\section{Introduction}

Sanitation is a critical issue in Africa today. The galloping urbanization and the rapid industrialization of African cities make the task of the structures in charge of waste management (wastewater) complex because they do not have the necessary means and tools, and appropriate for the evacuation of wastewater. outside the cities. Urbanization is a source of great economic opportunities, but also a challenge that requires a substantial reform of development policy programs. The emergence of the notion of sustainable development has reinforced this trend. In addition, it is impossible today to dissociate sustainable development from sanitation, the role of which is to make the environment healthy, to eliminate the causes of pollution or insalubrity for the well-being and the best conditions of people's lives. In view of these requirements for sustainable development, Ouagadougou, the capital of Burkina Faso, should not be the exception.

This study will highlight the harmful effects of the waste discharged into the open sewers on the environment and on the local population by measuring the physicochemical parameters. 


\section{Materials and Method}

\subsection{Choice of Study Devices}

\section{The site}

The treatment station: it is located in the industrial zone of Kossodo, located northeast of the city of Ouagadougou, in district 4. Domestic and industrial waste conveyed through these sewers is dumped directly into the said station.

Central canal: it is an open sewer passing through the city center, Yalgado hospital, Kossodo industrial zone

Wemtenga canal: it consists of open sewers passing through Dassasgho, Maco, Kossodo industrial zone

Zogona Canal: it concerns the open sewer passing through Zogona, Professor Ki ZERBO University, Kossodo industrial zone

Mogho Naaba Canal: it is also an open sewer, and the most important. It drains the Samandin, Gounghin, Camp Guillaume, Bilbambili, Ouidi, Nemnin districts as well as the Gounghin industrial zone.

Ph meter: This instrument was used for $\mathrm{pH}$ measurements of wastewater in open sewers (central channel, wemtenga channel, zogona channel and mogho naaba channel).

The $\mathrm{pH}$ meter consists of an electronic box allowing the display of the digital value of the $\mathrm{pH}$ and of a $\mathrm{pH}$ probe made up of a glass electrode allowing the measurement and a reference electrode. Its operation is based on the relationship that exists between the concentration of ions (definition of $\mathrm{pH}$ ) and the difference in electrochemical potential that is established in the $\mathrm{pH}$ meter when it is immersed in wastewater.

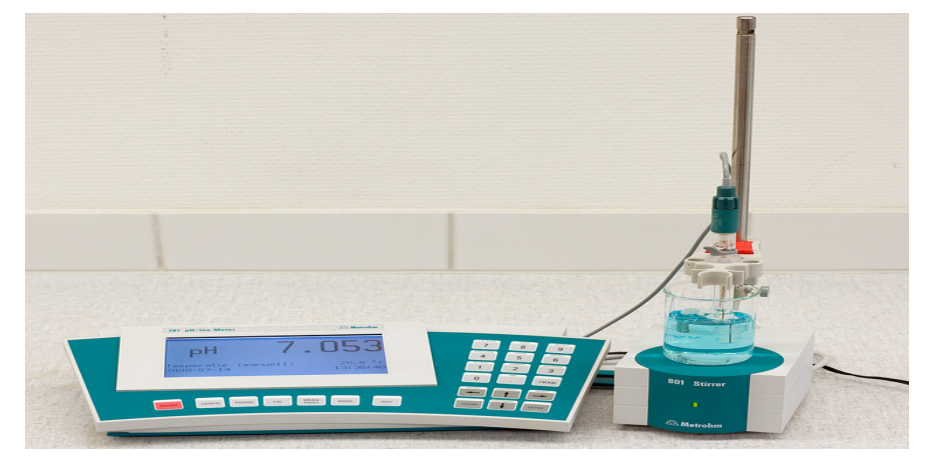

Figure 1. The $\mathrm{pH}$ meter to measure the $\mathrm{pH}$ of the E.U of the channels

\section{Microscope}

It is an optical instrument equipped with a lens and an eyepiece which allows to observe the possible presence of bacteria and viruses present in wastewater so that they can be observed by the human eye. 


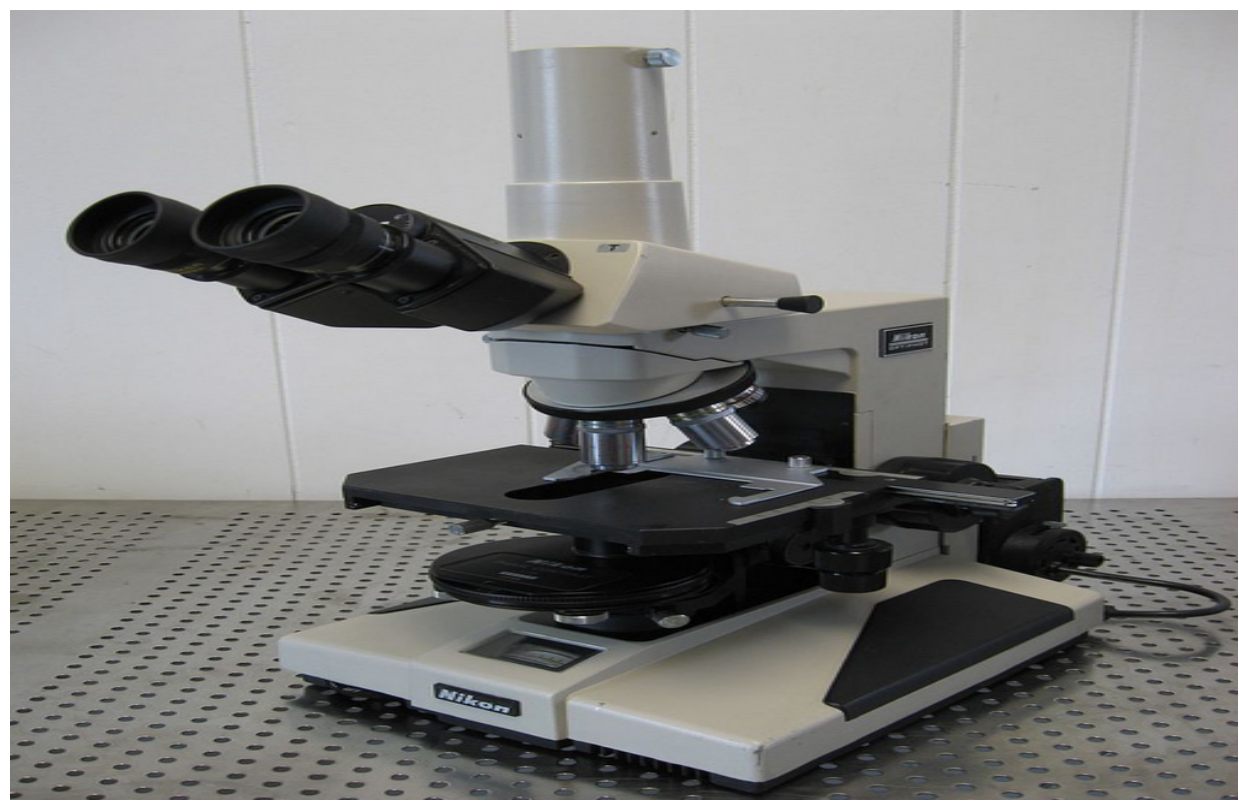

Figure 2. Microscope used to evaluate the microbiological parameters of the channels

WTW Cellox 325 oximeter: This instrument was used for the measurement of dissolved oxygen. The DCO determination was made on samples filtered with $0.45 \mu \mathrm{m}$ membranes, diluted and measured by the potassium dichromate method using a HACH spectrophotometer.

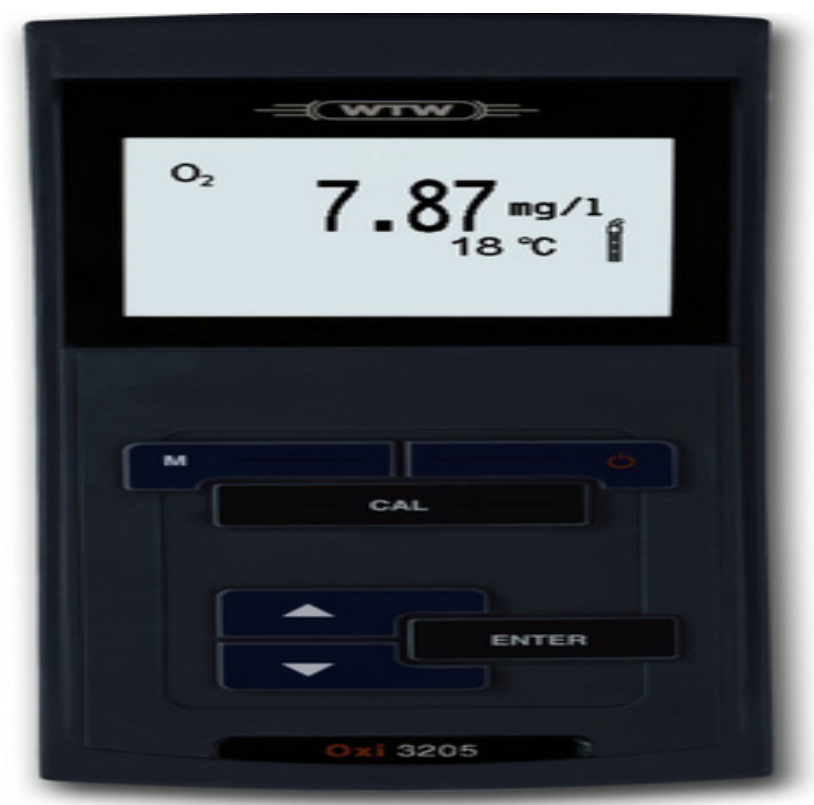

Figure 3. Oximeter measuring the DCO of the channels

A conductivity meter or conductivity meter: this is a device for measuring the conductivity of wastewater contained in open sewers. It consists of two parts: an electronic box which displays the value of the conductivity and a cell which measures this value.

The conductivity measurement is done in alternating current to avoid polarization of the electrodes. The device measures the voltage at the terminals of a cell immersed in the waste water to be studied and the intensity of the current flowing there. 


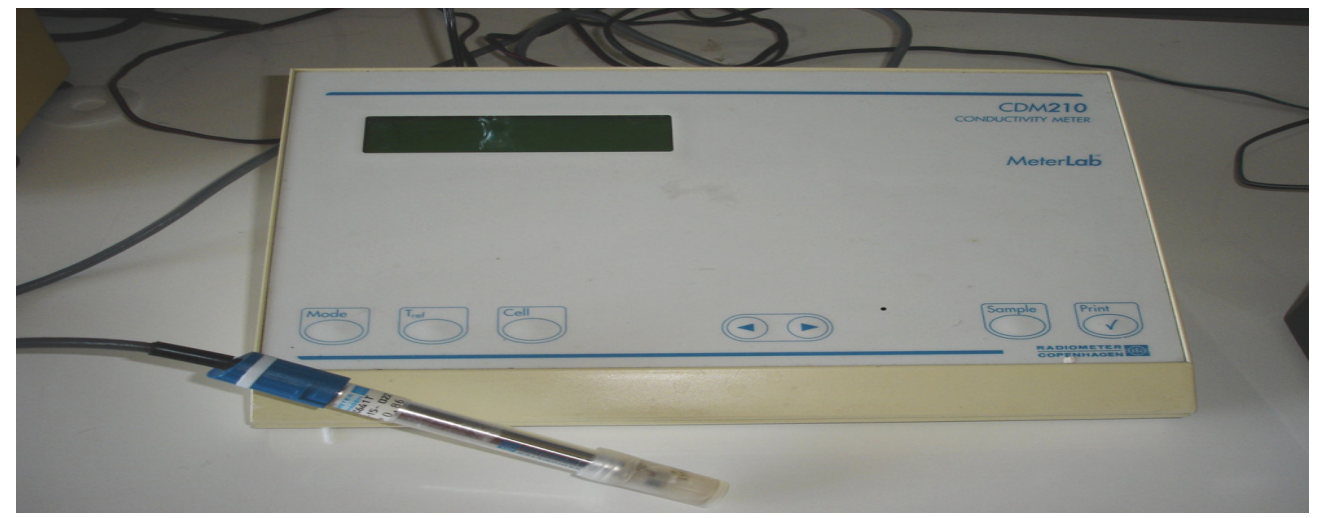

Figure 4. Digital conductivity meter measuring the electrical conductivity of the E.Us of the channels

Beaker or graduated beaker with handle

Bucket with rope

Rod sump (telescopic) with holder and suitable cup / container (graduated) adapted

a portable digital thermometer or thermocouple with an accuracy of up to $0.1^{\circ} \mathrm{C}$

plastic and / or glass containers for the (physico-chemical) parameters to be analyzed (pre-preserved, if applicable).

2.2 Description of the Study

\section{* Water sampling}

For questions of complexity, it is difficult to make a judicious choice of sampling points. However, the recognition of the wastewater discharge network made it possible to opt for ten sampling points on each major drainage network, namely: ten points symbolized by P1, P2, P3, P4, P5, P6, P7, P8, P9, P10.

These privileged sampling points are shown in the figure below. 


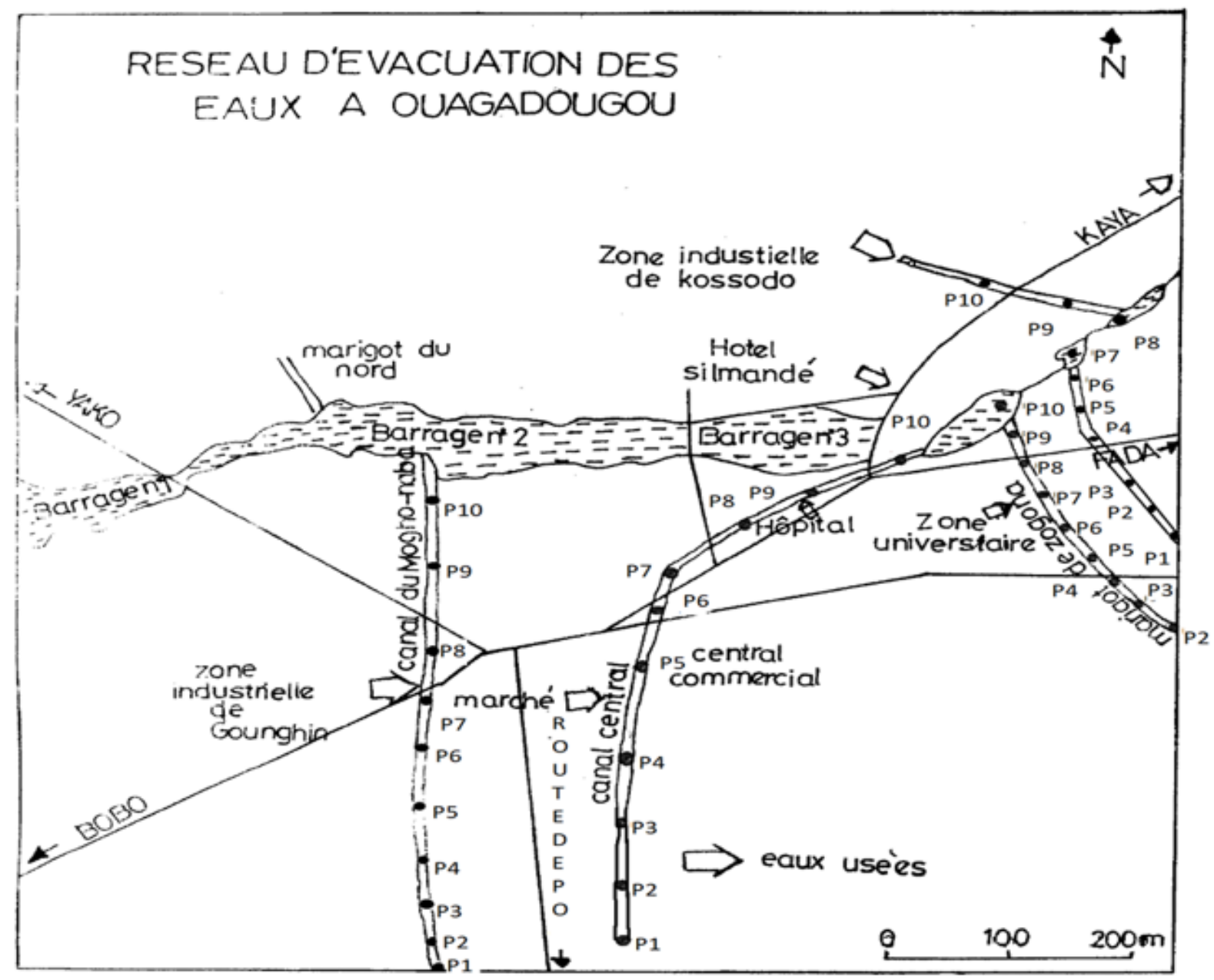

Figure 5. The water drainage network in the city of Ouagadougou where the sampling points are materialized

\section{- Sample collection}

Wastewater has a more or less variable composition depending on the season. It was difficult to practice a satisfactory sampling technique in the rainy season. Sampling was used in the dry season with the advantage of more reliable data since in the rainy season the rainwater reduces the impact.

The used water samples were taken in a liter plastic bottles, previously washed with distilled water. In order to control and confirm the reproducibility of the measurements of these parameters, additional samples were taken whenever necessary. The samples were kept in a refrigerated cooler during transport to the laboratory where analyzes were immediately carried out. During the analyzes, the samples are kept in the refrigerator to avoid any contamination and to ensure good conservation.

\section{Results and Discussions}

The results of the laboratory analyze for the physico-chemical parameters of the wastewater are presented in the tables and figures below:

Suspended matter: MES 
Table 1. Suspended matter (MES) per channel (mg/l)

\begin{tabular}{ccccc}
\hline Points & $\begin{array}{c}\text { Central } \\
\text { canal }\end{array}$ & $\begin{array}{c}\text { Wemtenga } \\
\text { canal }\end{array}$ & $\begin{array}{c}\text { Zogona } \\
\text { canal }\end{array}$ & $\begin{array}{c}\text { Mogho } \\
\text { Naaba } \\
\text { canal }\end{array}$ \\
\hline P1 & 950 & 820 & 840 & 750 \\
P2 & 960 & 891 & 850 & 771 \\
P3 & 960 & 743 & 850 & 633 \\
P4 & 970 & 952 & 860 & 842 \\
P5 & 970 & 950 & 860 & 840 \\
P6 & 990 & 1025 & 880 & 925 \\
P7 & 1026 & 1130 & 916 & 1030 \\
P8 & 1350 & 1150 & 1240 & 1050 \\
P9 & 1425 & 1250 & 1305 & 1150 \\
P10 & 1430 & 1120 & 1310 & 1020 \\
\hline
\end{tabular}

CURVES OF M.E.S IN FUNCTION OF SEWERS

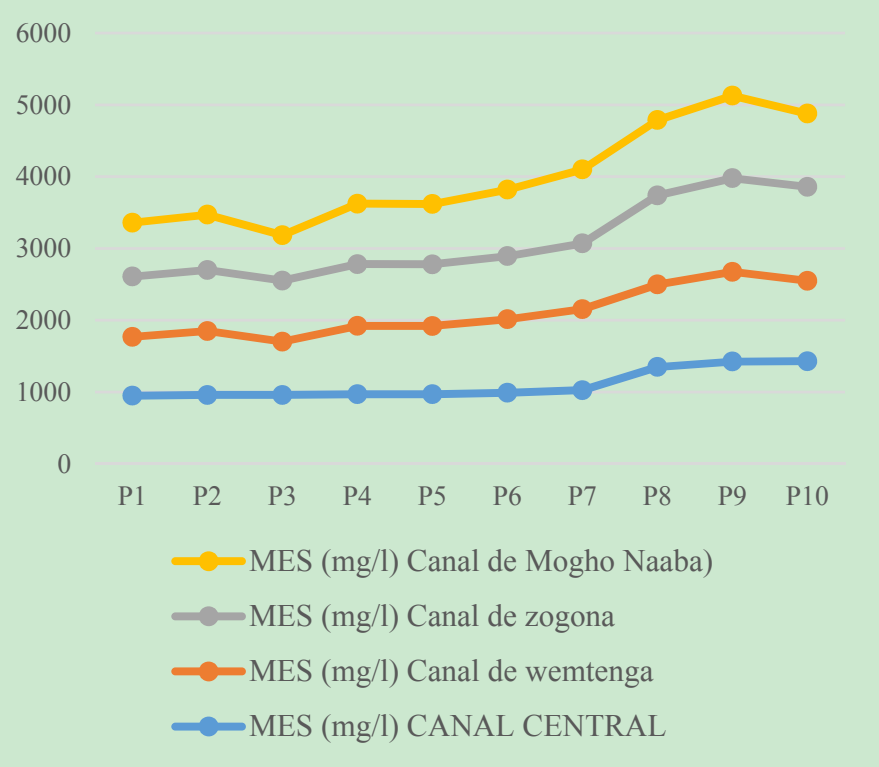

Figures 6. Trends in suspended solids as a function

of sewers (canals)

The analysis of the suspended matter curves of the channels (figure 6) shows an increase in the suspended matter content (MES) as the wastewater approaches the place of convergence (bangré-weogo park), which is higher than the limit value set before discharge into public sewerage systems at $1000 \mathrm{mg} / \mathrm{l}$.

The central sewer (central channel) from P1 to P6 the MES values are lower than the limit values provided for by the decree, from P7 to P10 the MES values are greater than the limit values. This situation is explained by the fact that from the city center (large market) to the Yalgado hospital we have a small amount of suspended solids (MES) in the central sewer and from the Yalgado hospital at Kossodo (industrial zone) we have a high concentration of MES. This increase is due to the activity of industrial companies and the discharge of wastewater into the sewer of Yalgado Hospital.

The wemtenga sewer (wemtenga channel) from P1 to P5 the MES values are lower than the limit values provided for by the decree, from P6 to P10 the MES values are higher than the limit values. This situation is explained by the fact that from the Wemtenga district to the Ouagodougou Arrest and Correction Center (MACO) we have a small amount of suspended solids (MES) in the sewer and MACO at Kossodo (industrial zone) we have a high concentration of MES. This is due to the activity of industrial companies and the discharge of wastewater into the MACO sewer.

The zogona sewer (zogona canal) from P1 to P7 the MES values are lower than the limit values provided for by the decree, from P8 to P10 the MES values are greater than the limit values. This is explained by the fact that from the Bonsyaar district to Professor Joseph KI Zerbo University (Ouaga I University) we have a small amount of suspended solids (MES) in the sewer and the Ouaga I University in Kossodo (industrial zone) we have a high concentration of MES due to the activity of industrial companies and the discharge of wastewater into the sewer of Ouaga I University.

- The Mogho Naaba sewer (mogho naaba canal) from P1 to P6 the MES values are lower than the limit values provided for by the decree, from P7 to P10 the MES values are higher than the limit values. This situation is explained by the fact that from the Cissin district to the Gounghin district we have a small quantity of suspended solids (SS) in the sewer and from the Gounghin district to dams $\mathrm{n}^{\circ} 1, \mathrm{n}^{\circ} 2$ and $\mathrm{n}^{\circ} 3$ until Kossodo (industrial zone) we have a high concentration of suspended solids. This is due to the activity of industrial companies in Gounghin and Kossodo each housing an industrial zone.

It is essential to install a filter system at the point of intersection (in the bangré-weogo park) of the canals (sewers) in order to avoid the rejection of MES in the natural environment, the consequences of which are harmful for the ecosystem in the bangé-weogo park and in the massili. 
Table 2. Demand of Chemical Oxygen per channel (mg/l)

\begin{tabular}{lllll}
\hline Points & $\begin{array}{l}\text { Central } \\
\text { canal }\end{array}$ & $\begin{array}{l}\text { Wemtenga } \\
\text { canal }\end{array}$ & $\begin{array}{l}\text { Zogona } \\
\text { canal }\end{array}$ & $\begin{array}{l}\text { Mogho } \\
\text { Naaba } \\
\text { canal }\end{array}$ \\
\hline P1 & 425 & 2720 & 325 & 1720 \\
P2 & 428 & 4950 & 324 & 3950 \\
P3 & 520 & 6510 & 422 & 5512 \\
P4 & 532 & 920 & 430 & 820 \\
P5 & 532 & 3300 & 432 & 1302 \\
P6 & 612 & 2500 & 510 & 1501 \\
P7 & 702 & 3025 & 602 & 2023 \\
P8 & 815 & 3040 & 712 & 2040 \\
P9 & 950 & 4025 & 852 & 3025 \\
P10 & 990 & 4060 & 892 & 3065 \\
\hline
\end{tabular}

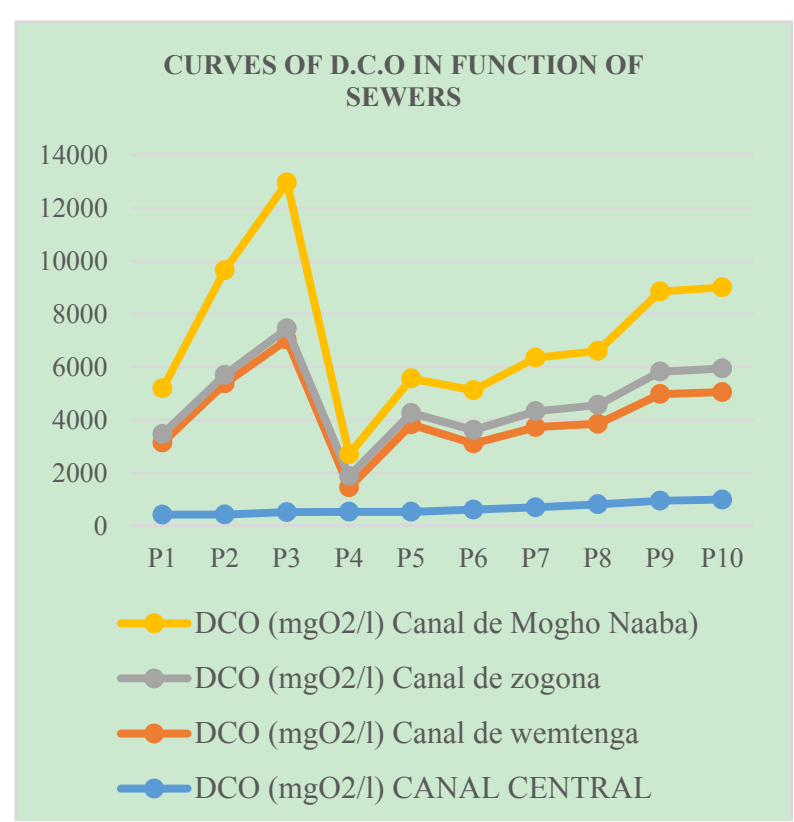

Figures 7. Trends in chemical oxygen demand by sewer

(canals)

Analysis of the trend curves of chemical oxygen demands as a function of the sewers (Figures 7) shows linear growth in chemical oxygen demands for the central channel and a sawtooth growth for the channels of wemtenga, zogona, mogho naaba. We notice an increase in the DCO content as we approach the point of convergence towards the industrial zone (bangé -weogo park). This increase in DCO concentrations in the open canals to the area is due to discharges from industrial units that gravitate in the area. The limit values for DCO discharges into public sewers are set by the structures in charge of sanitation (ONEA) according to each industrial unit.

The limit values for DCO in public sewers are $2000 \mathrm{mg} / 1$. The effluents from these canals are discharged directly into the massili via the bangré-weogo park without treatment. There is an urgent need to take measures to reduce the impact of this flow polluting the environment. The limit values for DCO discharge into the natural environment are $150 \mathrm{mg} / \mathrm{l}$. however, the DCO trends in the channels which will be poured into the massili (environment) are clearly greater than $150 \mathrm{mg} / \mathrm{l}$.

\section{Demand of Biochemical Oxygen in 5 days: DBO5}


Table 3. Demand of Biochemical Oxygen in 5 days per channel (mg/l)

\begin{tabular}{lllll}
\hline Points & $\begin{array}{l}\text { Canal } \\
\text { central }\end{array}$ & $\begin{array}{l}\text { Wemtenga } \\
\text { canal }\end{array}$ & $\begin{array}{l}\text { Zogona } \\
\text { canal }\end{array}$ & $\begin{array}{l}\text { Mogho } \\
\text { Naaba } \\
\text { canal }\end{array}$ \\
\hline P1 & 26 & 65 & 16 & 55 \\
P2 & 26 & 70 & 16 & 60 \\
P3 & 41 & 80 & 31 & 70 \\
P4 & 54 & 85 & 44 & 75 \\
P5 & 54 & 88 & 44 & 78 \\
P6 & 60 & 95 & 50 & 85 \\
P7 & 60 & 75 & 50 & 65 \\
P8 & 65 & 80 & 55 & 70 \\
P9 & 69 & 90 & 59 & 80 \\
P10 & 72 & 95 & 62 & 85 \\
\hline
\end{tabular}

\section{CURVES OF D.B.O 5 IN FUNCTION OF SEWERS}

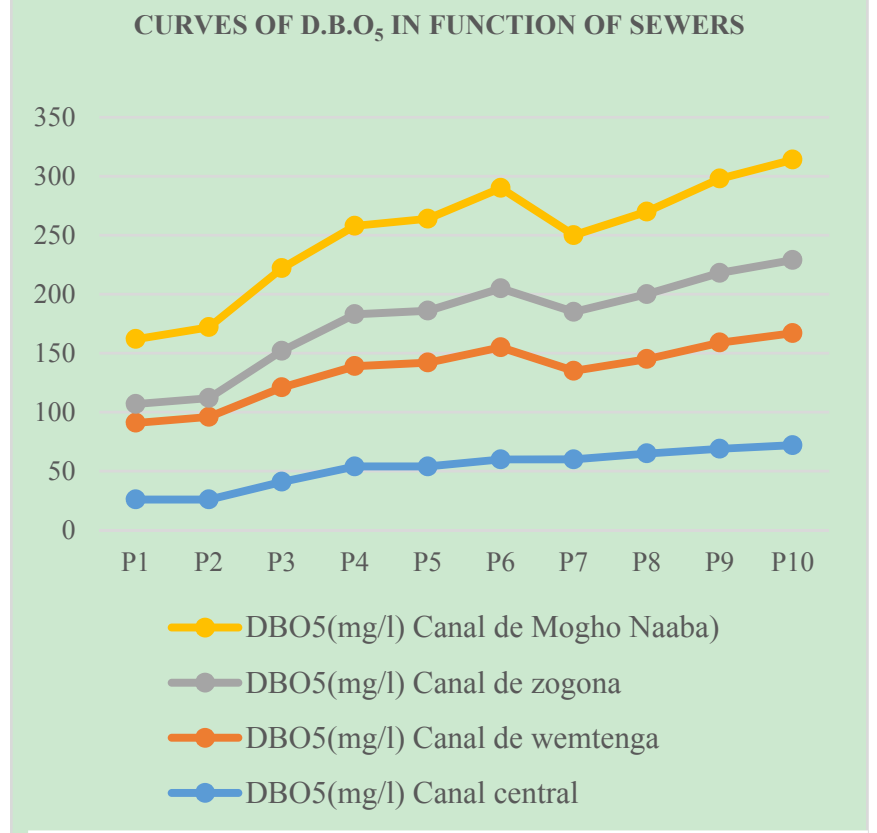

Figures 8. Trends in 5-day biochemical oxygen demand as a function of sewers (canals)

Analysis of the trend curves of biochemical oxygen demand in 5 days per channel (Figure 8) indicates an increase in $\mathrm{DBO}_{5}$ content as one approaches the industrial zone. This increase in $\mathrm{DBO}_{5}$ concentrations is explained by the discharge into open public sewers of wastewater from industrial units. If no measures have been taken for $\mathrm{DBO}_{5}$ trends, this will have serious consequences on the ecosystem of the bangré -weogo park and the massili which receives these effluents. The limit value of $\mathrm{DBO}_{5}$ for discharge into the natural environment (environment) at 40 $\mathrm{mg} / \mathrm{l}$. However, the concentrations of $\mathrm{DBO}_{5}$ in the open canals have exceeded the authorized environmental release threshold, so diligent measures are essential to reduce the impact of this pollution.

\section{The hydrogen potential: pH}

Table 4. Hydrogen potential per channel

\begin{tabular}{ccccc}
\hline Points & $\begin{array}{l}\text { Central } \\
\text { Canal }\end{array}$ & $\begin{array}{l}\text { Wemtenga } \\
\text { canal }\end{array}$ & $\begin{array}{l}\text { Zogona } \\
\text { canal }\end{array}$ & $\begin{array}{l}\text { Mogho } \\
\text { Naaba } \\
\text { canal }\end{array}$ \\
\hline P1 & 7,5 & 6,2 & 6,8 & 7,5 \\
P2 & 7,5 & 5,5 & 6,7 & 7,4 \\
P3 & 8 & 6,7 & 6,9 & 8,3 \\
P4 & 8,1 & 6,6 & 7,1 & 7,8 \\
P5 & 8 & 6,5 & 6,7 & 7,5 \\
P6 & 8 & 6,3 & 7,3 & 7,6 \\
P7 & 7,8 & 7,2 & 7,2 & 7,8 \\
P8 & 8 & 7 & 7,2 & 8,2 \\
P9 & 9 & 8,1 & 6,9 & 8,6 \\
P10 & 9 & 9 & 7,3 & 8,1 \\
\hline
\end{tabular}

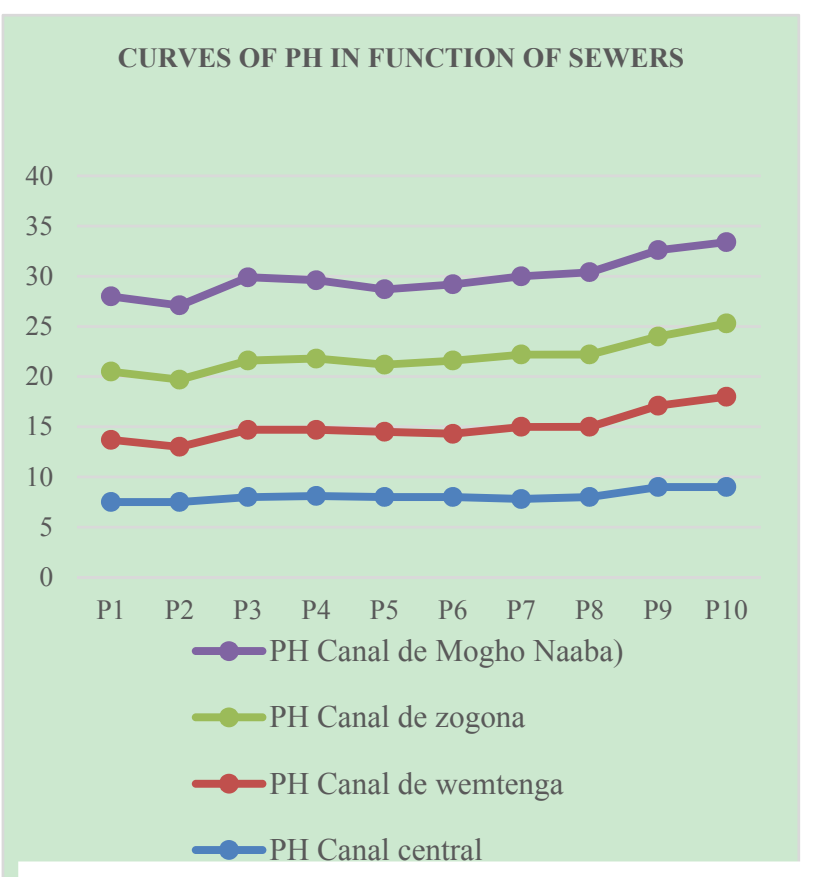

Figures 9. Trend of hydrogen potentials as a function of sewers (channels) 
According to the analysis of the trend curves of the hydrogen potentials (figure 9) the $\mathrm{pH}$ increases as one approaches the industrial area. It takes maximum values from the start of the industrial zone. This is justified by the discharge of effluents from industrial units which are rich in hydrogen potential. Quite true, the $\mathrm{pH}$ values in the sewers are below the discharge threshold authorized by the Burkinabe authorities, $\mathrm{pH}$ between 6.5 and 9.0 for a discharge of effluents into the natural environment and $\mathrm{pH}$ between 6.5 and 10.5 for discharge into sewers (canals); it is necessary to take appropriate measures to stop this increase.

\section{(r) Potassium}

Table 5. Potassium per channel (mg/l)

\begin{tabular}{ccccc}
\hline Points & $\begin{array}{c}\text { Central } \\
\text { canal }\end{array}$ & $\begin{array}{c}\text { Wemtenga } \\
\text { canal }\end{array}$ & $\begin{array}{c}\text { Zogona } \\
\text { canal }\end{array}$ & $\begin{array}{c}\text { Mogho } \\
\text { Naaba } \\
\text { canal }\end{array}$ \\
\hline P1 & 32,24 & 26,8 & 42,4 & 35,8 \\
P2 & 38 & 28,2 & 48,2 & 35,1 \\
P3 & 42,9 & 30,1 & 52,2 & 40,4 \\
P4 & 46,6 & 40,15 & 55,6 & 50,5 \\
P5 & 50,5 & 42,6 & 60,52 & 52,35 \\
P6 & 53 & 50 & 64 & 60 \\
P7 & 51,5 & 52,1 & 61,3 & 62,8 \\
P8 & 38,5 & 54 & 48,32 & 67 \\
P9 & 36,5 & 61 & 47,5 & 75 \\
P10 & 40,5 & 62,2 & 50,4 & 72,8 \\
\hline
\end{tabular}

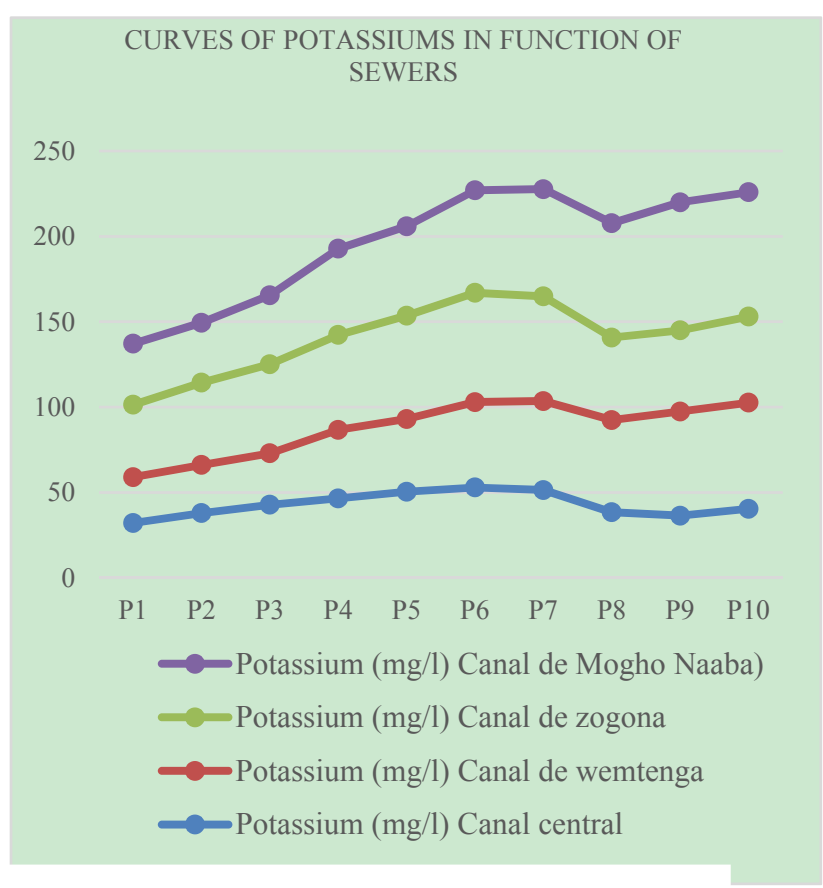

Figures 10. Potassium trend as a function of sewers (canals)

Analysis of the potassium trend curves as a function of the channels (Figure 10) shows an increase in potassium content with a maximum of P6 and P7. Then from P8 the potassium trend rises to reach its maximum value. This increase in the potassium concentration as one moves towards the area is explained by the discharge of effluents from industrial units. This rejection is much more important when we are in the area because of the density of industrial societies.

In order to protect the environment by reducing the negative impact, it is essential to force all industrial units to treat their effluent before it is released into the natural environment.

\section{Sodium}


Tableau 6. Sodium by canal (mg/l)

\begin{tabular}{ccccc}
\hline Points & $\begin{array}{c}\text { Central } \\
\text { canal }\end{array}$ & $\begin{array}{c}\text { Wemtenga } \\
\text { canal }\end{array}$ & $\begin{array}{c}\text { Zogona } \\
\text { canal }\end{array}$ & $\begin{array}{c}\text { Mogho } \\
\text { Naaba } \\
\text { canal }\end{array}$ \\
\hline P1 & 96 & 76 & 105,5 & 519,5 \\
P2 & 115 & 65 & 123 & 342,5 \\
P3 & 122 & 85 & 111,5 & 466,5 \\
P4 & 156 & 97 & 320 & 613 \\
P5 & 365 & 152 & 243,5 & 230,5 \\
P6 & 505 & 165 & 421,5 & 326 \\
P7 & 408 & 172 & 273,5 & 427 \\
P8 & 307 & 180 & 431,5 & 456 \\
P9 & 307 & 190 & 350 & 520 \\
P10 & 906 & 198 & 328 & 530 \\
\hline
\end{tabular}

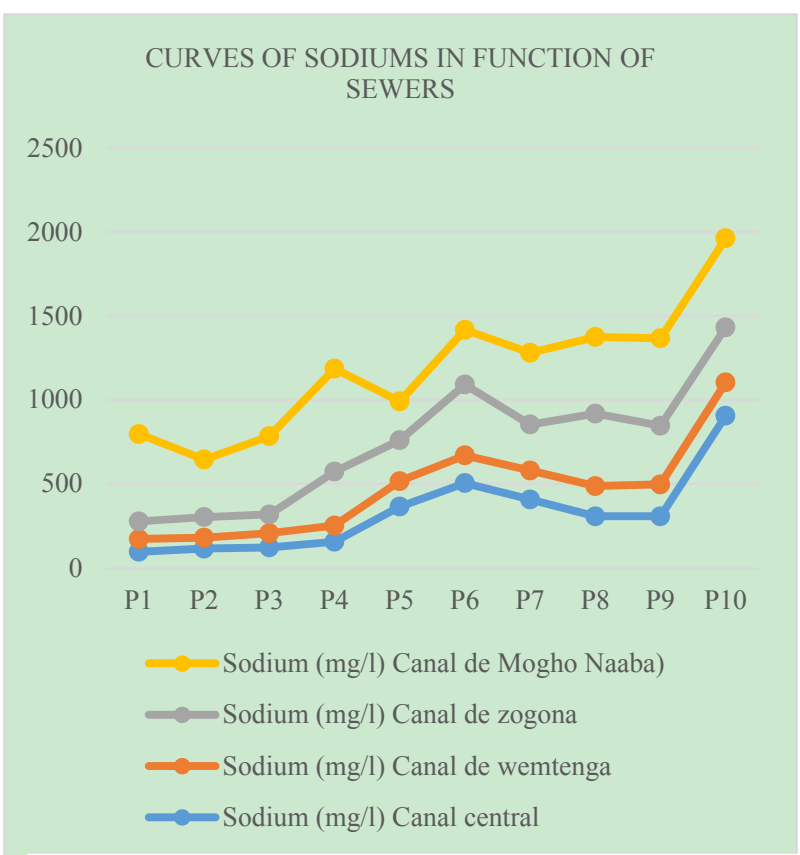

Figures 11. Sodium trend as a function of sewers (canals)

Based on the analysis of the sodium trendlines as a function of the channels (Figure 11) we have an increase in sodium content from $\mathrm{P} 1$ to $\mathrm{P} 10$ with a maximum at point P10.

Point P10 is located in the industrial zone, which justifies the high sodium concentration values at this point because of the effluents from industrial units. Quick decisions should be taken to reduce this concentration for the sake of environmental protection and public health.

\section{Conclusion}

The experimental study carried out in this work is a contribution to the protection of the environment in order to meet certain requirements of green industry. The results of the study show that there is pollution of the entire ecosystem with greater acuity at the level of the open-air industrial effluent evacuation sewers of the industrial zone in the city of Ouagadougou. Our results confirm most of the studies carried out on industrial wastewater. As the impacts of the physico-chemical parameters of the wastewater from the industrial zone are not all immediate, these waters could have a negative impact on human health and the environment in the long term.

In addition, the non-open sewer system in the sewage disposal networks would play an important role in mitigating the effects of pollution, however, the intensification of industrial activities in the Kossodo area in the city of Ouagadougou, because of the non-treatment of the effluents and the dysfunction of certain existing settling tanks, would be a risk for the pollution of the soil and consequently of the water table.

It would be interesting to extend the additional studies on the fauna and flora of the bangre-weogo park and its surroundings which drains the effluent as far as the Massili, as well as the measurement of the pollution of the water table in the vicinity of the water pipes. evacuation where the population practices intensive agriculture.

\section{References}

Al., A. -I. (2019). Impact of industrial wastewater discharge on the physico-chemical quality of. Kara: Africa Science.

Daniel, A. O., \& George, P. (1976). Collection and disposal of wastewater from communities. Geneva Switzerland: World Health Organization.

Fontes, J., \& Guinko, S. (1995). Map of the natural vegetation and land use of Burkina Faso. University of Ouagadougou: ICIV. University of Toulouse.

François, G. B. (2012). Distribution and collection of water. Montreal: Distribution and collection of water.

INSD. (2015). Ouagadougou: Statistical yearbook 2014. INSD Ministry of Economy and Finance, Burkina Faso, $386 \mathrm{p}$.

Kerloc'H, B., \& Maelstaf, D. (2014, January 1). The Sizing of Sanitation Networks in Agglomerations. Retrieved 
from

https://www.pseau.org/outils/ouvrages/cerema_le_dimensonnement_des_reseaux_d_assainissement_pour_1 es_agglomerations_2014.pdf

LAROUSSE. (2000). Retrieved from https://www.larousse.fr/dictionnaires/francais/assainir/5771

Morocco, R. D. (2002). Treatment and reuse of urban wastewater. Marrakech: CNRST.

O.N.E.A. (2001). Ministry of the Environment and of the National Water and Sanitation Office. Ouagadougou: E535 VOLUME 8.

OECD. (2020, February 07). Dynamics of African Urbanization 2020. Retrieved from https://www.oecdilibrary.org/development/dynamiques-de-1-urbanisation-african-2020_481c7f49-en

Ouedraqgo, S. (1997-1998). Evacuation of domestic wastewater and human excreta in Ouagadougou.

PSNA. (2007). National Sanitation Policy and Strategy (PSNA). Ouagadougou. CICAD report - Burkina. (1996). Ouagadougou.

Radoux, M. (1995). Water quality and treatment. Brussels: Luxembourg University Foundation, Viville Experimental Station.

RTB. (2020, September 09). Burkina: the council has decided to declare a state of natural disaster"government spokesman. Retrieved from https://www.rtb.bf: https://www.rtb.bf/2020/09/burkina-le-conseil-a-decide-dedeclarer-letat-de-catastrophe-naturelle-abdoul- karim-sango

Sawadogo, G. J., Teko-Agbo, A., \& Akpo, Y. (2005). Reuse of wastewater in agriculture in Senegal: impact on health and the environment in report Workshop-seminar on treatment and reuse of wastewater: impact on health and the environment on March 3-6. Rabat: IAV.

SIDWAYA. (2017, August 22). Wastewater recovery: Faecal sludge treatment plants, fine examples. Retrieved from $\mathrm{http}: / /$ news.aouaga.com/h/110462.html

Sp/Conagese, C. G. (2002). First Report of the State of the Environment in Burkina Faso. Ouagadougou: CONAGESE Ministry of Environment and Water (MEE), Burkina Faso, 194p.

Wethe, J. (2006). Collection and treatment of wastewater. Ouagadougou: EIER - ETSHER.

WIKIPEDIA. (2020, June 14). Retrieved from https://fr.wikipedia.org/wiki/ Sanitation

WIKIPEDIA. (2020, June 27). Network. Retrieved from https://fr.wikipedia.org/wiki/R\%C3\%A9seau

\section{Copyrights}

Copyright for this article is retained by the author(s), with first publication rights granted to the journal.

This is an open-access article distributed under the terms and conditions of the Creative Commons Attribution license (http://creativecommons.org/licenses/by/4.0/). 